\title{
The Survival Rate of Grafted-Seedling of Durian (Durio zibhetinus Murr.) in the Indigenous Agroforestry Orchards of Osingnese in Banyuwangi, East Java, Indonesia
}

\author{
Abu Naim ${ }^{1 *}$, Luchman Hakim ${ }^{2}$, Serafinah Indriyani ${ }^{2}$ \\ ${ }^{1}$ Master Program of Biology, Faculty of Mathematics and Natural Sciences, University of Brawijaya, \\ Jl. Veteran 65145 Malang, Indonesia \\ ${ }^{2}$ Department of Biology, Faculty of Mathematics and Natural Sciences, University of Brawijaya, \\ Jl. Veteran 65145 Malang, Indonesia \\ *naimrahmatullah87@gmail.com
}

\begin{abstract}
We aimed to assess survival rate of grafted-seedling of local Durian (Durio zibhetinus) in the Osingnese orchards Banyuwangi. This study mapped the location of wild seedling distribution, grafting of durian seedling, and evaluating the survival rate of grafted-seedling growth. Wild seedling mapping used GPS and coordinates of seedling and analyzed spatially using QGIS 2.8. Individual rootstock for grafting was selected from wild seedling in types of open and close canopy orchards. Grafting experiment used three red durian variants: $D B, R X$, and BMS as scion. Each orchard experiment 6 grafting treatments and 5 repetitions. Survival rate was observed every 2 weeks after grafting. Survival rate compared the percentage of living and dead scion. Growth models was analyzed by multivariate Clusters and biplot on PAST. The best percentage of scion survival rate shows by $D B$ variant in the first orchard under close canopy (80\%) and BMS in the third orchard in close canopy (60\%). Adaptation analyzed by scion characters growth consists of three groups. The less adaptive character (first group): BMS- $K_{1}-O, B M S-K_{2}-C, B M S-K_{2}-O, B M S-K_{3}-O, D B-K_{2}-O, D B-K_{3}-O, R X-$ $K_{1}-O, R X-K_{2}-O$, and $R X-K_{3}-O$. Second, group of adaptive character: $D B-K_{I}-O, D B-K_{2}-C, D B-K_{3}-C, R X-K_{I}-C$, $R X-K_{2}-C, R X-K_{3}-C$, and $B M S-K_{1}-C$. Third group with more adaptive character includes $D B-K_{1}-C$ and $B M S$ $\mathrm{K}_{3} \mathrm{C}$.
\end{abstract}

Keywords: red durian, grafting, orchard, agroforestry

\author{
Abbreviations \\ Dubang (DB) \\ Reed Extra (RX) \\ Bumisari (BMS) \\ Weeks After Grafting (WAG) \\ Quantum Geographic Information System (QGIS) \\ Paleontological Statistic (PAST) \\ BMS- $\mathrm{K}_{1}-\mathrm{C} \quad$ : Bumisari Orchard 1 Close Canopy \\ BMS- $\mathrm{K}_{1}-\mathrm{O} \quad$ : Bumisari Orchard 1 Open Canopy \\ BMS- $\mathrm{K}_{2}-\mathrm{C} \quad$ : Bumisari Orchard 2 Close Canopy \\ BMS- $\mathrm{K}_{2}-\mathrm{O}$ : Bumisari Orchard 2 Open Canopy \\ BMS- $\mathrm{K}_{3}-\mathrm{C}$ : Bumisari Orchard 3 Close Canopy \\ BMS- $\mathrm{K}_{3}-\mathrm{O}$ : Bumisari Orchard 3 Open Canopy \\ DB- $\mathrm{K}_{1}-\mathrm{C} \quad$ : Dubang Orchard 1 Close Canopy \\ DB- $\mathrm{K}_{1}-\mathrm{O} \quad$ : Dubang Orchard 1 Open Canopy \\ DB- $\mathrm{K}_{2}-\mathrm{C} \quad$ : Dubang Orchard 2 Close Canopy
}




\begin{tabular}{|c|c|}
\hline $\mathrm{DB}-\mathrm{K}_{2}-\mathrm{O}$ & : Dubang Orchard 2 Open Canopy \\
\hline $\mathrm{DB}-\mathrm{K}_{3}-\mathrm{C}$ & : Dubang Orchard 3 Close Canopy \\
\hline $\mathrm{DB}-\mathrm{K}_{3}-\mathrm{O}$ & : Dubang Orchard 3 Open Canopy \\
\hline $\mathrm{RX}-\mathrm{K}_{1}-\mathrm{C}$ & : Reed Extra Orchard 1 Close Canopy \\
\hline $\mathrm{RX}-\mathrm{K}_{1}-\mathrm{O}$ & : Reed Extra Orchard 1 Open Canopy \\
\hline $\mathrm{RX}-\mathrm{K}_{2}-\mathrm{C}$ & : Reed Extra Orchard 2 Close Canopy \\
\hline $\mathrm{RX}-\mathrm{K}_{2}-\mathrm{O}$ & : Reed Extra Orchard 2 Open Canopy \\
\hline $\mathrm{RX}-\mathrm{K}_{3}-\mathrm{C}$ & : Reed Extra Orchard 3 Close Canopy \\
\hline $\mathrm{RX}-\mathrm{K}_{3}-\mathrm{O}$ & : Reed Extra Orchard 3 Open Canopy \\
\hline
\end{tabular}

\section{INTRODUCTION}

Durian (Durio zibethinus Murr.) is native to southeastern Asia [1]. In Southeast Asia region, Indonesia is one of the centers for genetic diversity of durian [2].The genetic variety of durian in Indonesia provides important germplasm for breeding durian plants in Indonesia [3]. In Indonesia, durians mostly found in home garden of local people, especially home garden and orchards which area managed through agro forestry systems. In such system, durian grows with other three species such mangosteen, coffee and coconut.

Banyuwangi is one of the potential areas for durian development. Local people, locally called Osingnese, traditionally cultivated durian in orchards and home gardens surrounding local settlement. There are about 82,143.63 ha (14-21\% of the region Banyuwangi) of orchards in Banyuwangi which are potential for crops and fruit plant development, including durians [3].In Banyuwangi, however, durian production is still low. The productivity of durian in 2012 was about 5,888.5 tons or 152.00 quintals/ha [4].Compared to the other regency in East Java, the production of Durian in Banyuwangi was low. Statistical report shows that Pasuruan has production of about 84,670 tons. Trenggalek regency able to produce durian about 24,990 tons, and Malang produce about 15,140 tons [5].

Grafting is one of the methods to improve durian trees to produce high quality of fruits. Grafting technique has been used to increase properties of plants, including fix heterosis, save endangered species, create a quality of a good crop, and regulate size plant [6], control sex differentiation, scatter the seeds and virus free-saplings, set the period of ripeness [7], and determine genetic stability of some clonal variation [8]. Grafting wild durians seedling in indigenous orchards become the important strategy to improve future durian tree productivity [9].It is especially important in Banyuwangi regency. This study aimed to assess survival rate of grafted-seedling of local Durian $(D$. zibhetinus Murr.) in the Osingnese orchards, Banyuwangi.

\section{Material AND Methods}

\subsection{Study Site}
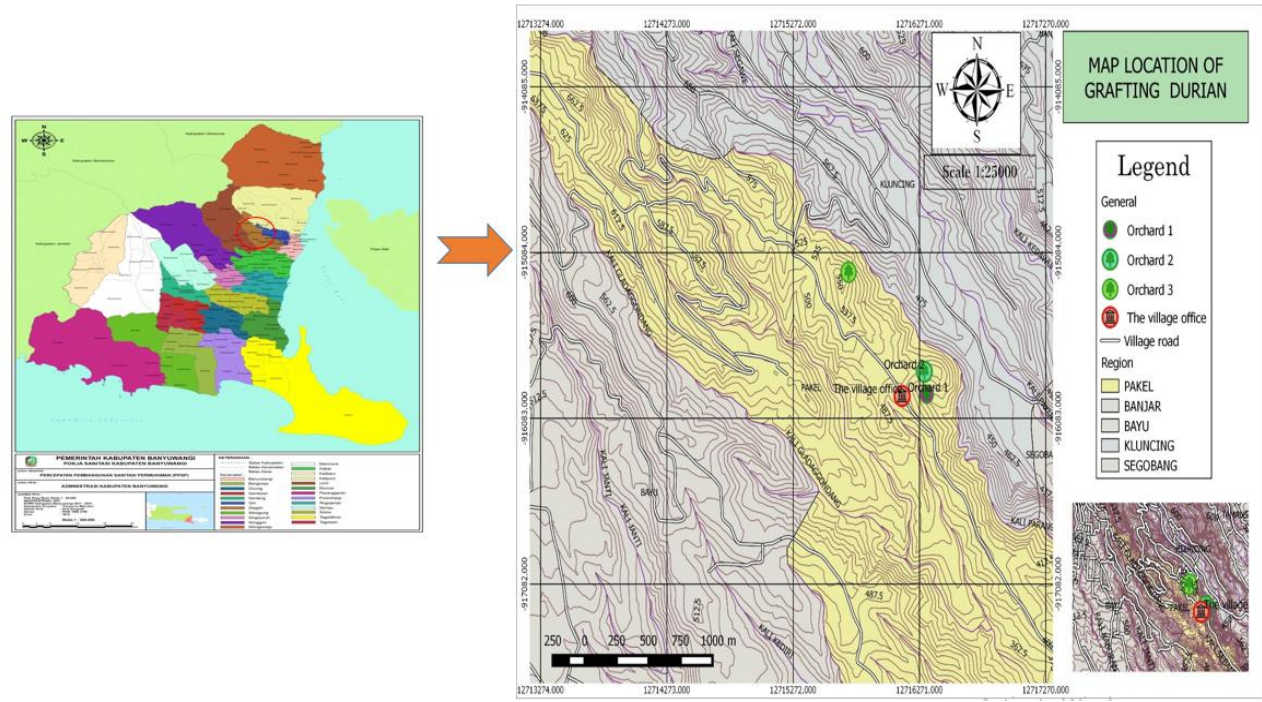
The survival rate of grafted-seedling of durian (Durio zibhetinus Murr.) in the indigenous agroforestry orchards of Osingnese in Banyuwangi, East Java, Indonesia

Figure 1. The location of study sites and orchards for grafting experiment in the field in Osingnese

This study was conducted in Pakel village (Licin) in Banyuwangi district, East Java, Indonesia on February-November 2015 . The area was located at the coordinates $08^{\circ} 11^{\prime} 59.9^{\prime \prime} \mathrm{N}, 114^{\circ} 13^{\prime} 51,5^{\prime \prime} \mathrm{E}$. This area is located in the slope of Mts. Ijen and having contour highlands at 300-600 m asl with a slope 15-40\%. Average rainfall was $157 \mathrm{~mm}$ with the lowest precipitation is in the ends of November (33.7 mm), while the highest rainfall occurs in January (306 mm) [4].

The field research experiment was set up at three locations (Fig.1). The orchards experiments are spread around the main road of Pakel village. The distance of each orchard experiments with residential areas is $100-500 \mathrm{~m}$. The experimental orchards ranged $0.54-1$ ha at different altitude. The first orchard located at the altitude of 400-450 m asl, the second orchard located at altitude of 450-500 $\mathrm{m}$ asl and the third orchard located at altitude of 500-550 $\mathrm{m}$ asl.

\subsection{Mapping the Distribution of Wild Seed Durian in the Experiment Orchard}

The orchard experiment and the location of growing wild seed Durian experiment was mapped with recording data coordinates through Global Positioning System (GPS). Target of mapping was mature individual durian and other trees which are grow in orchards. Coordinate data is mapped and spatially analyzed by application of Quantum Geographic Information System (QGIS) 2.8 (wien) [10]. Map data was analyzed through overlay techniques with contours map which is resulting from ASTER GDEM V2 image (a product of METI and NASA).The overlay process also used digital earth maps of Indonesia, Licin sub-district 2006 sheets of 1707-432 as references. Coordinates data was processed further by use the geo-processing feature tools using Quantum GIS.

\subsection{Grafting Wild Seedling Durian}

The selected individual rootstock of durian for grafting was seedling with having age 4-5 months and height of 30-60 cm. Three red durian variants include of Dubang (DB), Reed Extra (RX), and Bumisari (BMS) was used as scion. Design for the experiment was following Randomized Complete Block Design. In each orchard, 6 grafting experiment was done with combination seedling location and scion sources were: open $+\mathrm{RX}$, open $+\mathrm{DB}$, open $+\mathrm{BMS}$, close $+\mathrm{Rx}$, close $+\mathrm{DB}$, and close + BMS, in 5 repetitions, with total about 90 grafted seedlings. The observation on survival rates of scion and grafted individual was observed 2 weeks after grafting (WAG). Observation was done periodically every two weeks. Observation was stopped in 12 WAG.

\subsection{Data Analysis}

Survival rate analysis of grafting result was done by the calculation on survive scion and dead scion. Data was tabulated in Microsoft Excel 2010 to find out the percentage rate survival scion from experiments. Analysis of scion growth was done to understand the scion character growth of three variants superior durian Banyuwangi which based on treatments. Analysis of multivariate Clusters and biplot used Paleontological Statistic (PAST) to find out grouping variant durian based on multivariate character of growth scion after grafting [11].

\section{RESULTS AND DISCUSSION}

\subsection{Distribution of Seedling}

The distribution of durian seedling in three experiment orchards was commonly clumped. There are tendency of seedling grows near the parent tree. Based on the plant height, seedling durian could be classified into two parts, seedling having height $30-60 \mathrm{~cm}$ and $1-2 \mathrm{~m}$.

In the first orchard, the growing seedling and grafting durian widely grew on slope $25-45 \%$ and spread at altitude of $415-475 \mathrm{~m}$ asl. Besides tree of durian, there are several plant which are significantly contributes to the canopy effect on orchards, namely Syzygium aqueum, Swietenia mahagoni L., Garcinia mangostana L., Mangifera indica, and Chrysophyllum cainito (Fig. 2a).In the second orchard, distribution seedling and grafting durian was spread at altitude of $462.5-487 \mathrm{~m}$ asl and most on slope $8-15 \%$ and slope $15-25 \%$. Other plant contributes to the canopy effect are $S$. aromaticum, S. Mahagoni L., G. Mangostana L., and C. cainito (Fig 2b).In the third orchard, distribution seedling and grafting durian was clumped at altitude of 560 and $540 \mathrm{~m}$ asl, it was 
Abu Naim et al.

clumped among slope $0-8 \%, 8-15 \%$ and $25-45 \%$. Several plants which are providing canopy impact to orchards are S. mahagoni L., G. Mangostana L., and C. Cainito (Fig 2c).

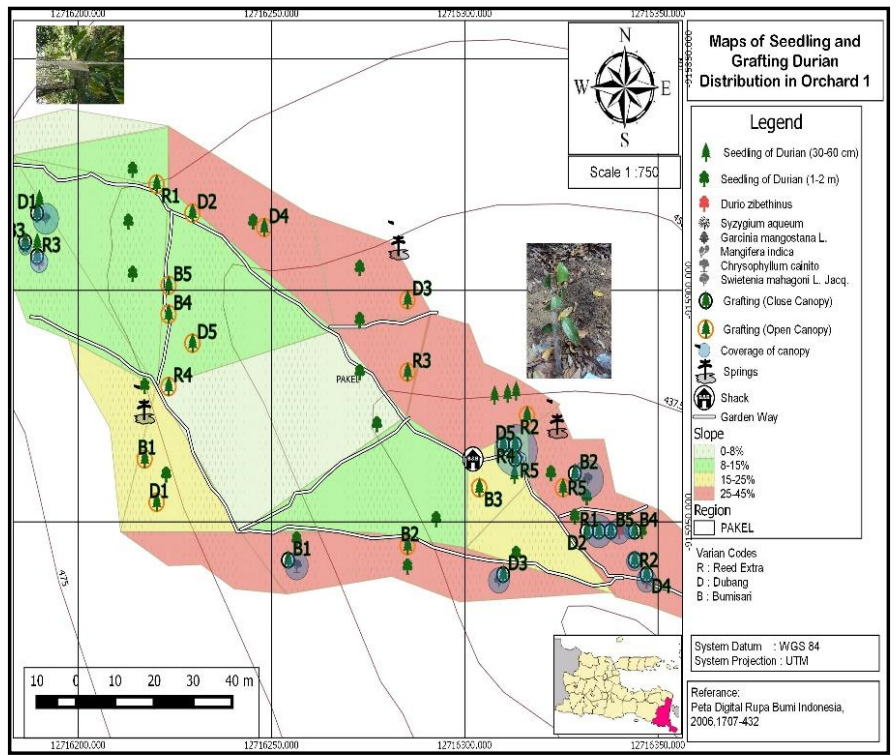

(a) First Orchards

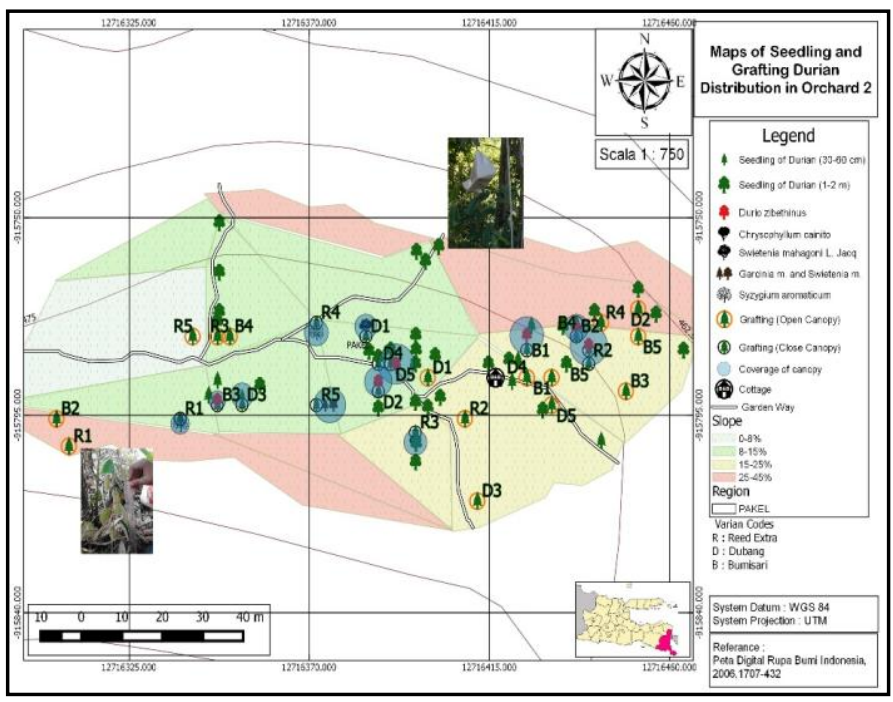

(b) Second orchards

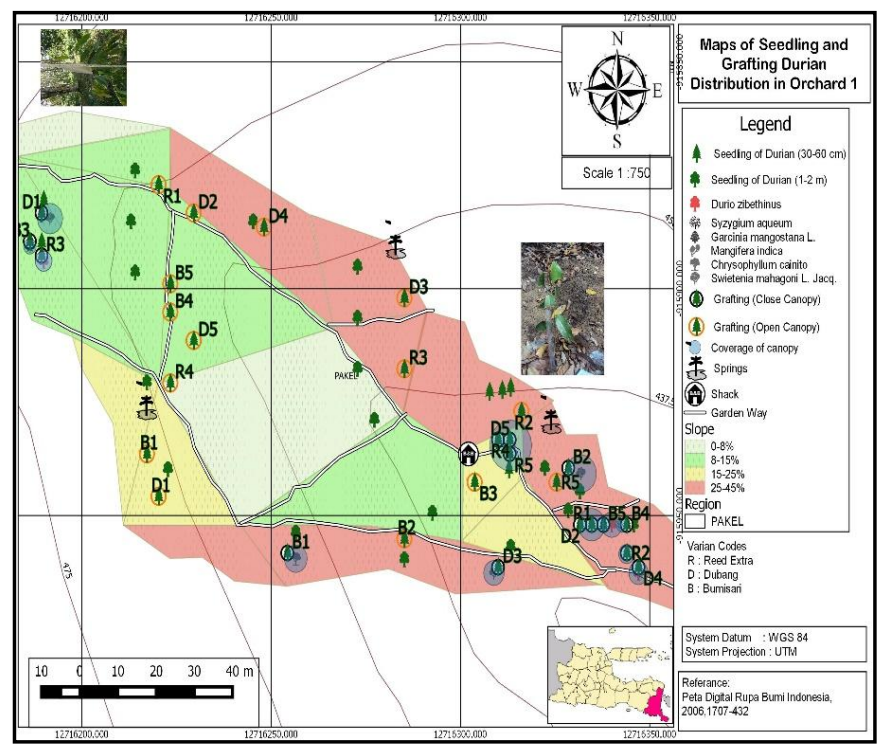

(c) third orchards 
The survival rate of grafted-seedling of durian (Durio zibhetinus Murr.) in the indigenous agroforestry orchards of Osingnese in Banyuwangi, East Java, Indonesia

Figure 2. Maps of seedling and grafting durian distribution in Osingnese orchards in Banyuwangi

(a) First Orchards (b) Second orchards (c) third orchards

The seedling distribution in surrounding area of parent tree point reflects the human impact of seedling distribution. Gardens owner often consume the mature fallen fruit near the parent durian tree (Fig. 2).Except the first orchard, the existence of two springs on a land with slope $25-45 \%$ plays an important role in the distribution of seedling. The availability of water and humidity is a requirement major in an earlier stage of life to undergo germination [12]. The springs are very important for determining the distribution pattern of species $[13,14]$.

Based on observations in the field, there are some species contributes to the canopy development which are affect durian seedling. These were found in three experiment orchard. This finding consistent with the research's result of previous research, that the Osingnese cultivates numerous fruit and woody trees species in home garden and orchards for numerous purposes[15]. This is known as agro forestry orchard. Agroforestry is important for economic stability of local people [16], and also contributes significantly in biodiversity conservation.

\subsection{Survival Rate of Scion and Grafted-Seedlings}

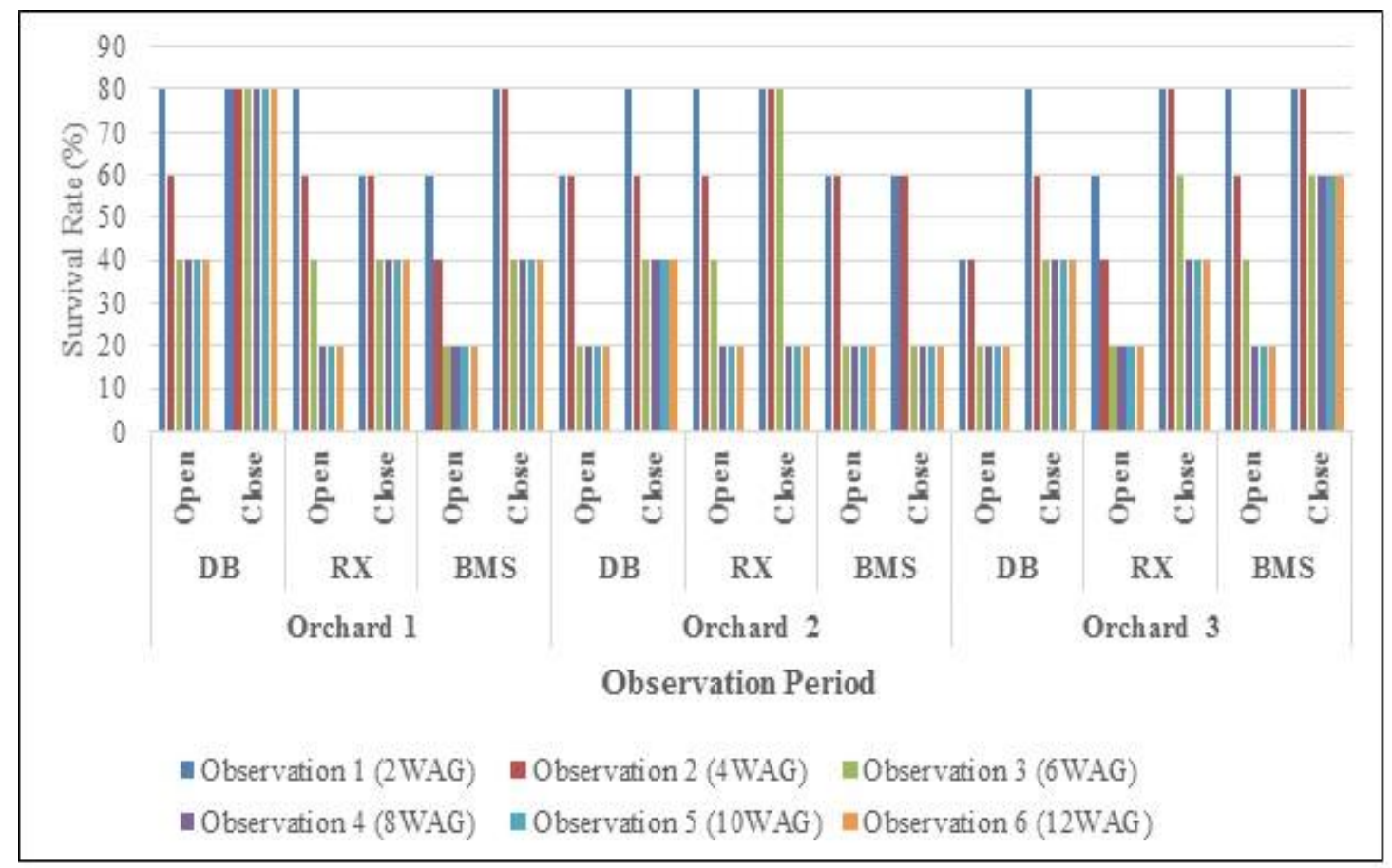

Figure 3. Survival rate of grafting durian in orchards Osing tribe Banyuwangi

The serial observation about survival rate of scion and grafted seedling is shown in Fig.3. Survival rate scion tended to be stable after fourth observation ( $8 \mathrm{WAG}$ ). The death scion occurred in $2 \mathrm{WAG}$ until 4 WAG. It could be caused by a failure of the unification of vascular tissue between scion and rootstock. Previous study mentioned there are three mechanism of rootstock-scion joining in early process of grafting, namely adhesion rootstock into the top (scion), proliferation of callus on interface (between incision) rootstocks and scion and the vascular interface differentiation in connection [17]. Scion will not succeed to continue its growth except vascular tissue is being connected. The proper joining of two tissues ensures the transportation of water, mineral and nutrients.

Based on the observations on 12 WAG, the highest survival rate is DB variant scion in the first orchard located in close canopy (80\%), and followed by BMS variant scion in the third orchard located in close canopy (60\%).DB variant seems to be compatible scion for grafting seedling in first orchards. BMS variant considered as better scion in grafting in the third orchard. Expert pointed out that grafting durian in the orchard influenced by environmental factors like temperature, moisture, and 
the intensity of light [17]. High temperature and low humidity air will increases the risk of a failure in the commission. Cambium and cells parenchyma consisting of callus tissue is a thin and soft so it is sensitive to drought [18].

\subsection{Height and Diameter of the Scion}

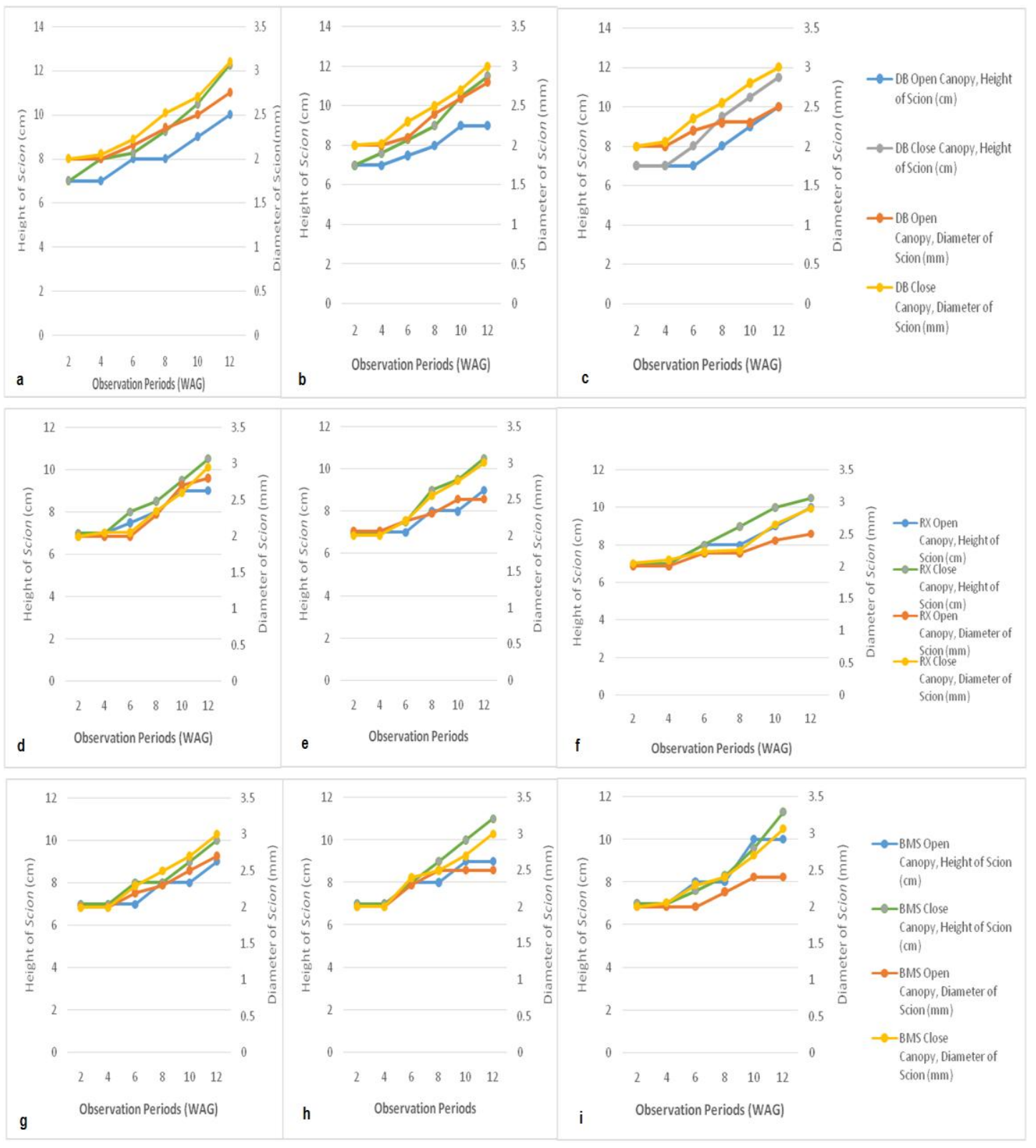

Figure 4. Height and diameter of scion

(a) Dubang (DB) variant in $1^{\text {st }}$ orchard, (b) in $2^{\text {nd }}$ orchard, (c) in $3^{\text {rd }}$ orchard, (d) Reed Extra $(R X)$ variant in $1^{s t}$ orchard, (e) in $2^{\text {nd }}$ orchard, (f)in $3^{\text {rd }}$ orchard, $(g)$ Bumisari $(B M S)$ variant in $1^{\text {st }}$ orchard, $(h)$ in $2^{\text {nd }}$ orchard, $(i)$ in $3^{\text {rd }}$ orchard

After $12 \mathrm{WAG}$, DB variant was having best average high scion in three grafting locations, i.e.12.25 $\mathrm{cm}$ in the first orchard, $11.5 \mathrm{~cm}$ in the second and third orchard (Fig. 4a,b,c).The average of scion height of DB variant in all locations indicates that the scion of DB variant grew better than the other variant.

The result of scion diameter measurement showed that DB, RX and BMS variant in close canopy has higher diameter compared to the scion in open canopy. In the first orchard, DB variant in close canopy has greatest diameter average $3.1 \mathrm{~mm}$ ( Fig.4a ), while the second orchards DB, RX and BMS variant in close canopy has an average of the greatest diameter $3 \mathrm{~mm}$ ( Fig.4b,e,h).In third orchard location, BMS variants in close canopy have the largest scion diameter (3.06 mm) (Fig.4i).

The rapid of growth of grafting diameter indicate that the grafting was going well [19]. The 
The survival rate of grafted-seedling of durian (Durio zibhetinus Murr.) in the indigenous agroforestry orchards of Osingnese in Banyuwangi, East Java, Indonesia

differences height of scion is influenced by the ability of rootstocks and scion in nutrient absorption and distribution from the root to leaf [20].

The results of overall, grafting in the area of close canopy had an average of height and diameter of scion that is better compared to the open canopy. This indicates that canopy contributes to the significant impact on the growth of scion height as the results of grafting. The existence of canopy affects the light intensity. Less intensity of light will tend to make plants to grow faster [21].

\subsection{Number of Leaves and Shoots in Scion}

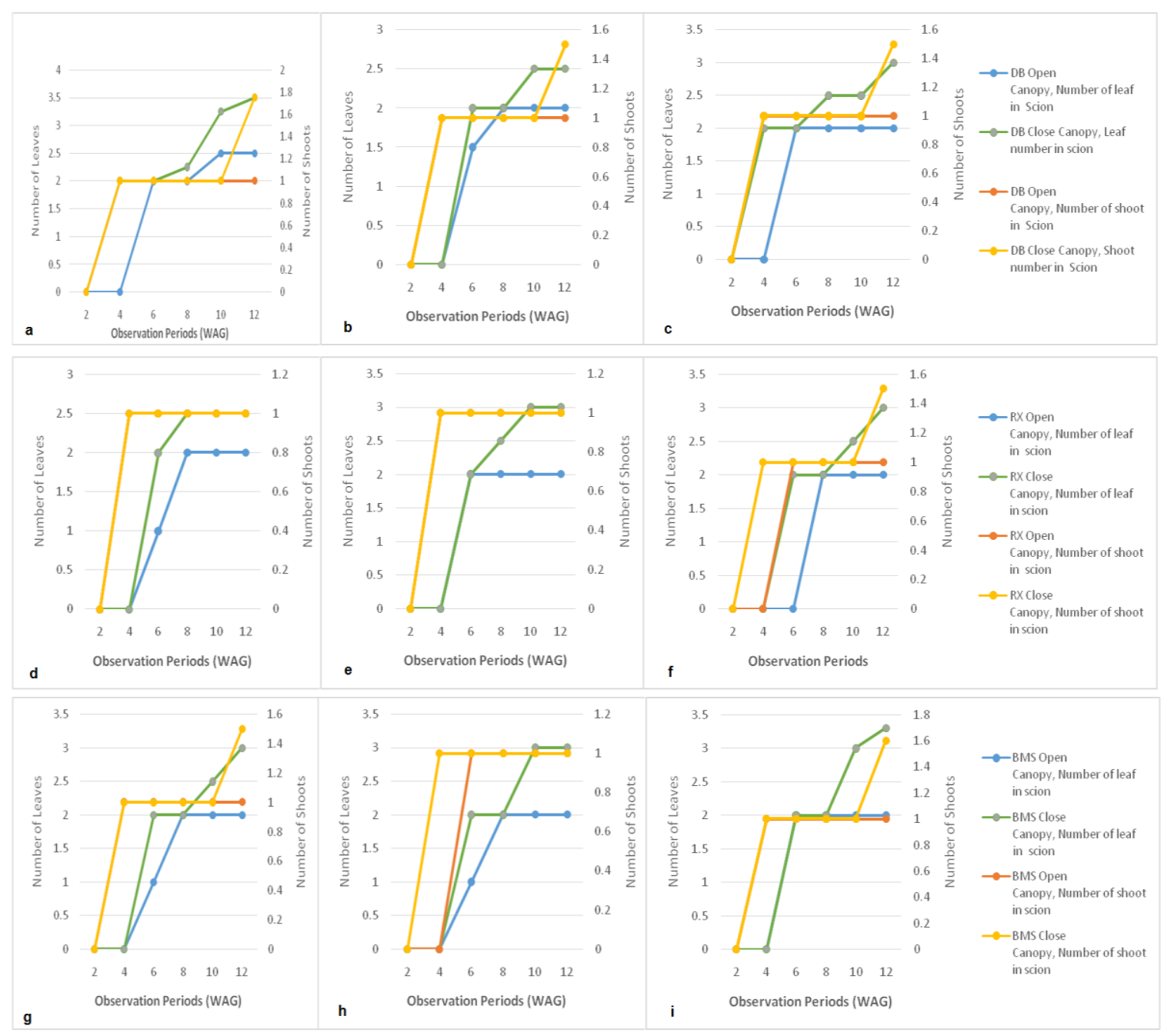

Figure 5. The average number of leaves and number of shoots in scion

(a) Dubang (DB) variant in $1^{\text {st }}$ orchard, (b) in $2^{\text {nd }}$ orchard, (c) in $3^{\text {rd }}$ orchard, (d) Reed Extra (RX) variant in $1^{s t}$ orchard, (e) in $2^{\text {nd }}$ orchard, $(f)$ in $3^{\text {rd }}$ orchard, $(g)$ Bumisari $(B M S)$ variant in $1^{\text {st }}$ orchard, $(h)$ in $2^{\text {nd }}$ orchard, (i) in $3^{\text {rd }}$ orchard.

The number of leaves in the scion of all variant used in grafting (DB, RX, and BMS) was highest in close canopy area compared to the open canopy area (Fig. 5). Based on observation in 12 WAG, DB variant in first orchards which is located in close canopy has highest number of leaves about 3.5 leaves in average. In second orchard, RX and BMS variant in close canopy have highest number of leaves about 3 leaves in average (Fig.5e, h). While in third orchard, variant BMS in close canopy having the highest average number of leaves about 3.3 leaves in average (Fig. 5i).

The number of shoots at $12 \mathrm{WAG}$ of the variant DB, RX and BMS on a close canopy area similar with number of shoots in open canopy. In first orchard, DB variant on close canopy an area has the largest number (1.75 shoots), while in second variant in close canopy having the highest number of shoots about 1.5 shoots. BMS variant in thirds area in close canopy having highest number of shoots about 1.6 shoots in average (Fig. 5) 
The high number of leaves of DB variant in close canopy in first orchard and BMS in close canopy in thirds orchards was caused by the success of join tissue between rootstocks and scion. The success of connection triggering transformation of mineral and water to all parts of scion that will affect the growth of leaves [22].

The high average number of shoots in first orchard was seems to berated into the environmental factor. The existence of water springs in first orchard contributes to the water resources availability for plants, including durian seedling, to establish area with abundance plant species. These causes the high level air humidity which is contributes to the plant seedling survival. Springs water also contributes to the water content in the soil [23].

\subsection{The Similarity Adaptation Scion of Several Durian Variant}

a

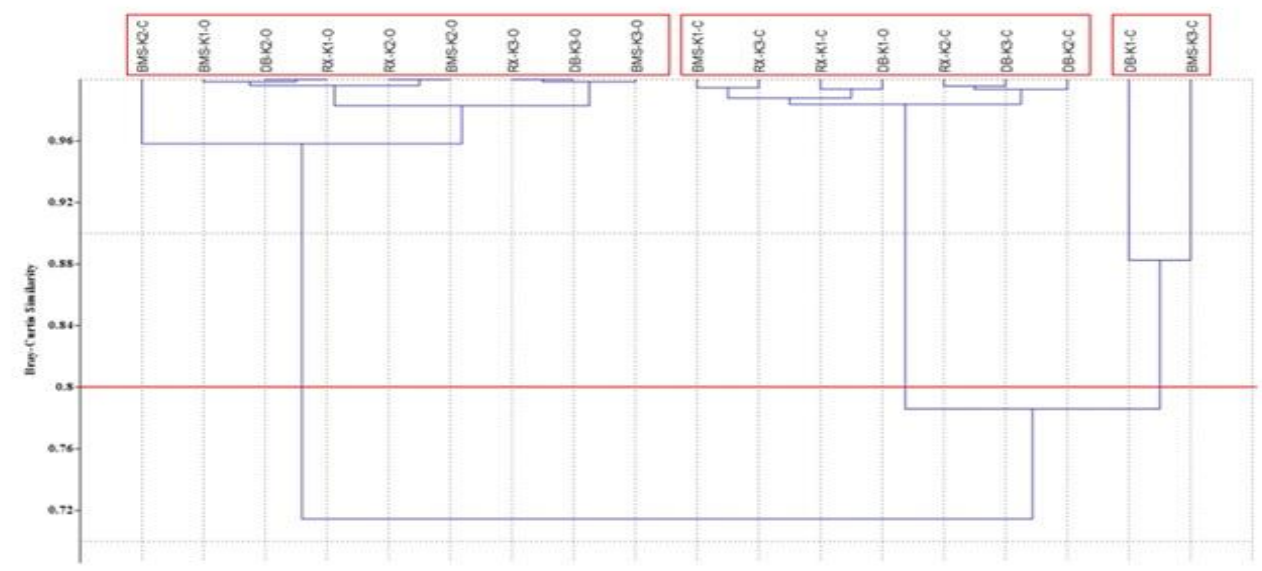

b

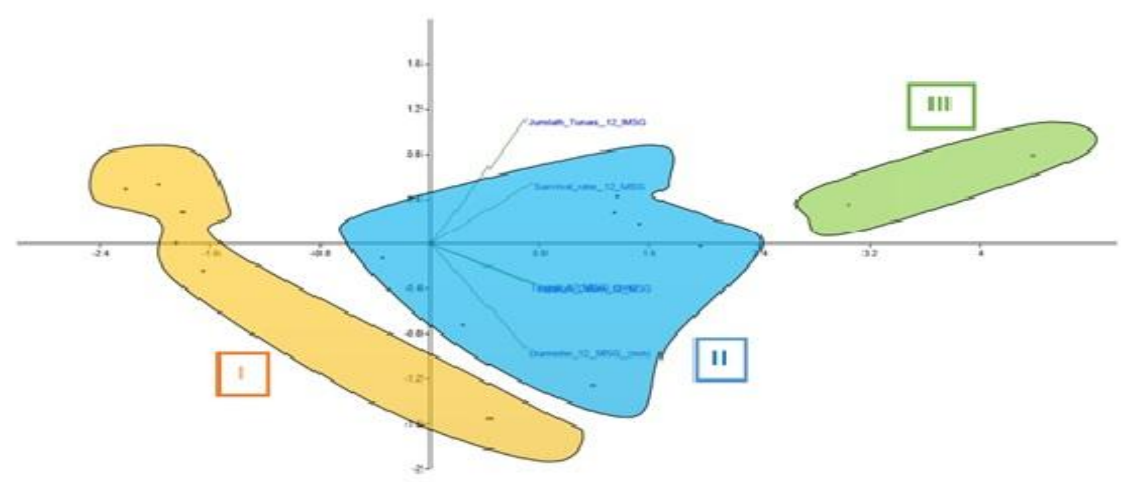

Figure 6. Grouping character of scion growing (a) cluster of growth scion (b) biplot of growth scion

The analysis of grouping character using clusters and biplot (PAST) in growth grafting scion durian results three characters of growth. Group I is characterized as less adaptive, the group II is adaptive and the group III is more adaptive (Fig. 6a). The first group characterized by the low value of all parameter growth as specified height, diameter, number of leaves, shoots, and survival rate. The second group has the adaptation ability better than the first orchards. It has high value on plant's height, diameter, number of leaves, shoots, and survival rate. The thirds groups are the most adaptive group which is characterized by the high value of growth parameters (Fig. 6b).

Group I is less adaptive such as: BMS-K2-C, BMS-K2-O, BMS-K1-O, BMS-K3-O, RX-K1-O, RX$\mathrm{K} 2-\mathrm{O}$, RX-K3-O, DB-K3-O, and DB-K2-O.Group II is adaptive such as is: RX-K1-C, RX-K2-C, RX$\mathrm{K} 3-\mathrm{C}$, DB-K2-C, DB-K3-C, DB-K1-O and BMS-K1-C. Group III is most adaptive that is DB-K1-C and BMS-K3-C. Increasing number of leaves growth, number of shoots, scion height and diameter seems to be related to both environmental and physiological aspect of grafted individuals. Therefore, for the success of grafting in the field, environmental conditions should be considered as a crucial factor.

\section{Conclusion}

The survival rate of grafting scion durian in the area of experiment shows that connection in close 
The survival rate of grafted-seedling of durian (Durio zibhetinus Murr.) in the indigenous agroforestry orchards of Osingnese in Banyuwangi, East Java, Indonesia

canopy is higher than in open canopy. In the first orchard, DB variant in close canopy having best survival rate about $80 \%$. In the second orchard, the best survival rate of DB and BMS scion variant in close canopy was $40 \%$. In the thirds orchard, BMS scion variant in close canopy having best survival rate about $60 \%$. The character of scion growth can be classified into three groups. Group 1 is less adaptive (BMS- $\mathrm{K}_{2}-\mathrm{C}, \mathrm{RX}-\mathrm{K}_{1}-\mathrm{O}, \mathrm{BMS}-\mathrm{K}_{1}-\mathrm{O}, \mathrm{RX}-\mathrm{K}_{2}-\mathrm{O}, \mathrm{BMS}-\mathrm{K}_{2}-\mathrm{O}, \mathrm{RX}-\mathrm{K}_{3}-\mathrm{O}, \mathrm{DB}-\mathrm{K}_{3}-\mathrm{O}, \mathrm{DB}-\mathrm{K}_{2}-\mathrm{O}$, BMS- $K_{3}-\mathrm{O}$ ), Group 2 is adaptive ( $\mathrm{RX}-\mathrm{K}_{2}-\mathrm{C}, \mathrm{RX}-\mathrm{K}_{1}-\mathrm{C}, \mathrm{RX}-\mathrm{K}_{3}-\mathrm{C}, \mathrm{DB}-\mathrm{K}_{2}-\mathrm{C}, \mathrm{DB}-\mathrm{K}_{3}-\mathrm{C}, \mathrm{DB}-\mathrm{K}_{1}-\mathrm{O}$, BMS- $\mathrm{K}_{1}-\mathrm{C}$ ), the third is more adaptive ( DB- $\mathrm{K}_{1}-\mathrm{C}$ and $\mathrm{BMS}-\mathrm{K}_{3}-\mathrm{C}$ ).

\section{ACKNOWLEDGEMENTS}

The author would like to thank the village head of Pakel, Licin Regency, Agro Banyuwangi team, and all the Osingnese that helping the study.

\section{REFERENCES}

[1] Ashraf M., Jamil M. and Yusoff I., Estimation of antioxidant Phytochemicals in four different varieties of Durian (Durio Zibethinus Murray) Fruit, Conference Proceeding, Int. Conference on Bioscience, Biochemistry and Bioinformatics, 5, pp 131-135, (2010).

[2] Hariyati T., Kusnadi J. and Arumingtyas E. L., Genetic diversity of hybrid durian resulted from cross breeding between Durio kutejensis and Durio zibethinus based on random amplified polymorphic DNAs (RAPDs), Am. J. Mol. Biol. 3, 153-157 (2013).

[3] Uji T. Keanekaragaman jenis dan sumber plasma nutfah Durio (Durio spp.) di Indonesia, Herbarium Bogoriense, Botany, Research Center of Biology-LIPI. Bull. Plasma Nutfah 11, 2833 (2005).

[4] BPS Banyuwangi, Kabupaten Banyuwangi dalam angka. Available: http://banyuwangikab.bps.go.id/ (2013).

[5] PPSP Banyuwangi, Buku putih sanitasi Kabupaten Banyuwangi. Available at: http://banyuwangikab.go.id/ (2012).

[6] Colla G., Rouphael Y., Cardarelli M., Salerno A. and Rea E., The effectiveness of grafting to improve alkalinity tolerance in watermelon. Environ. Exp. Bot. 8 (3), 283-291 (2010).

[7] Lee J. M., Kubota C., Tsao S. J., Bie Z., Echevarria P. H., Morra L. and Oda M., Current status of vegetable grafting: diffusion, grafting techniques, automation. Sci. Hortic. 127 (2), 93-105 (2010).

[8] Taller J., Hirata Y., Yagishita N., Kita M. and Ogata S., Graft-induced genetic changes and the inheritance of several characteristics in pepper (Capsicum annuum L.), Theor. Appl. Genet. 97 (5-6), 705-713 (1998).

[9] Rusmiati, Ashari S., Widodo M. A. and Bansir L., The nutritional composition of red durians from Banyuwangi, Indonesia. Food Sci. Qual. Manage. 37, 46-51 (2015).

[10] Quantum GIS Development Team. Quantum GIS Geographic Information System. Open Source Geospatial Foundation Project. Available at: http://qgis.osgeo.org (2015).

[11] Hariyati J. R., Kelulushidupan dan pertumbuhan beberapa bibit spesies pohon asli di lahan restorasi Ranu Pani - Ranu Regulo, Taman Nasional Bromo Tengger Semeru. Master Program of Biology, University of Brawijaya, Master Thesis, pp 28-29 (2013).

[12] Scheffer F. Lehrbuch der Bodenkunde. Enke, Stuttgart, Germany (1998).

[13] Lamont B. B., Enright N. J. and Bergl S. M., Coexistence and competitive exclusion of Banksia hookeriana in the presence of congeneric seedlings along a topographic gradient. Oikos 56, 3942 (1989).

[14] Gutterman Y. Seed germination in desert plants. Springer Verlag, Berlin, (1993).

[15] Zakiyah, Indriyani S. and Hakim L. Pemetaan sebaran dan karakter populasi tanaman buah di sepanjang koridor jalur wisata Desa Kemiren, Tamansuruh dan Kampunganyar, Kabupaten Banyuwangi, J. Ind. Tour. Dev. Std. 1 (2), 46-51 (2013).

[16] Campbell B. M., Clarke J. M. and Gumbo D.J., Traditional agroforestry practices in Zimbabwe. Agrofor. Syst. 14, 99-111 (1991).

[17] Hartmann H. T., Kester D. E., Davies F. T. and Geneve R. L., Plant propagation: principles and 
practices, $7^{\text {th }}$ Ed., Prentice Hall Inc., Upper Saddle River, NJ, pp.106-138 (2002).

[18] Doley D. and Leyton L., Effects of growth regulating substances and water potential on the development of wound callus in Fraxinus. New Phytol. 69, 87-102 (1970).

[19] Sudjijo. Pengaruh ukuran batang bawah dan batang atas terhadap pertumbuhan durian Monthong, Hepe, dan DCK-01. J. Hortikultura 19 (1), 89-94 (2009).

[20] Kusumo S., Sugita Y. and Solvia N., Tempat dan cara perbanyakan bibit Durian, J. Hort. 2(1), 23-26 (1992).

[21] Gardner F. P., Pearce R. B. and Mitchell R. L., Fisiologi tanaman budidaya. University of Indonesia, Jakarta, (1991).

[22] Soegito A., Soemargono and Rebin., Kompatibilitas antara batang bawah dan batang atas terhadap pertumbuhan mangga di daerah rendah basah. Faculty of Agriculture, University of Muhammad Yamin, J. Ilmu Pertanian Farming. 1(1), 121-126 (2002).

[23] Titus P., Bandem P. D., and Patriani, Pengaruh panjang entris terhadap keberhasilan sambung pucuk bibit jambu air, J. Sains Mahasiswa Pertanian 1, 1-9 (2012).

\section{AUTHORS' BiOgRAPHY :}

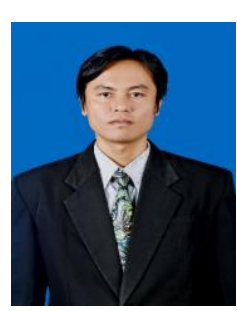

Abu Naim, born in $09^{\text {th }}$ October, 1987 in Tuban East Java. Master student of Department Biology, University of Brawijaya, Malang. Research focus about conservation of natural resources especially in orchard people of Banyuwangi, East Java. project under coordinator Dr. Luchman Hakim.

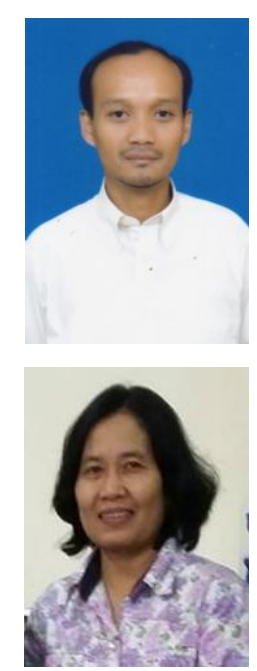

Luchman Hakim, born in Malang (1971). Head of the department of Biology, University of Brawijaya. Research focus about biological conservation and tourism development. He has wrote journals and books related to cultural landscape, conservation, indigenous knowledge and tourism development.

Serafinah Indriyani, born in Surabaya (1963) is a lecturer in Department Biology, Brawijaya University. Completed Doctoral Degree from Airlangga University at 2011. Recently she is working as head of Plant Taxonomy laboratory, Brawijaya University. Her research focus on the Botany and Agriculture. 